\title{
The Creation of the World in Jewish Esoteric Philosophy
}

by

Igor H. De Souza

Yale University

igor.h.desouza@yale.edu 


\begin{abstract}
A discussion of Création du monde et limites du langage. Sur l'art d'écrire des philosophes juifs médiévaux by David Lemler

About the Author

IGOR H. DE SouZA specializes in Jewish thought and gender studies. He is the author of Rewriting Maimonides, a study of medieval commentaries on the Guide of the Perplexed. His book in progress, The Pure People: Sodomy and the Jews, examines discourses on same-sex relations in pre-modern Judaism. He is currently a lecturer and research fellow at Yale University.
\end{abstract}




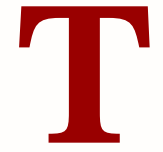

he notion of esoteric writing has been deeply influential in the study of medieval Jewish philosophical texts. David Lemler's Création du monde et limites du langage. Sur l'art d'écrire des philosophes juifs médiévaux ${ }^{1}$ is the most recent addition to a shelf that continues to grow since Leo Strauss' landmark studies on Maimonides' Guide of the Perplexed [Strauss 1952: cf. e.g., Halbertal 2007; Schwartz 2005, 149-222]. Strauss' argument is that Maimonides chose to express himself esoterically for political-religious reasons: the fear of persecution, stemming from the socially-fragile status of philosophers in the medieval world. Though not without detractors and critics, Strauss' basic approach to medieval Jewish philosophy-which he extends to much of Western philosophy, with Socrates' demise as a preeminent example of what takes place when philosophers are not careful-has been widely accepted among specialists. It bears noting that the esoteric approach to texts championed by Strauss was not original to him. Rather, he derives it from the earliest commentators on the Guide of the Perplexed who wrote in the 13th and 14th centuries, although he does not emphasize the historical predecessors of his approach.

The growing shelf on esotericism and esoteric language has expanded far beyond the boundaries of the study of medieval Jewish philosophy. Classicists and historians of philosophy have pointed out esoteric strategies in the writings of late-ancient readers of Aristotle and Plato. The well-known division of Aristotle's writings into acroamatic (exoteric) and akroatic (esoteric) disciplines is a strategy of esoteric writing [Boas 1953]. More recently, Arthur Melzer has proposed that virtually all philosophers until the modern age have written esoterically. His claim is actually stronger: it is that we cannot properly understand pre-modern philosophy if we ignore the esoteric dimension of philosophical writing [Melzer 2014]. Indeed, the argument has been made that esoteric writing reveals more than simply how people wrote: it reveals how they constructed the world [Talmage 1999].

While there is no universal definition of esoteric writing, we can point to some of its historical forms. Generally speaking, esoteric writing takes place

1 Études de Philosophie Médiévale 106. Paris: Vrin, 2020. Pp. 208. ISBN 978-2- 71162941-1. Paper $€ 19.00$ 
when an author attempts to conceal some aspect of their thought, for reasons that will be outlined below. A variety of strategies can then take place:

- employing purposeful contradictions within the same text;

- employing code-words or allusions, the significance of which will be grasped by some readers but not all;

- fashioning a general and surface explanation of some topic, only to put forward a deeper explanation of the same topic subsequently;

- providing distinct explanations of the same phenomenon in different works.

Esoteric works are said to contain two levels: one is the external, "exoteric" level, which any reader can access; and the other is the internal, "esoteric" level, which requires specific decoding skills on the part of readers. Esoteric writing is different from symbolism and metaphor, although it can employ either as a part of a larger rhetorical strategy. In esoteric writing, unlike symbolism and metaphor, the "surface" or exoteric level does not necessarily lose its rhetorical force even once a reader has been able to access the esoteric level. Both levels exist simultaneously, each carrying their own truths (which may or may not converge into the same truth).

As studies by Melzer and others have shown, there are many varieties of esoteric writing responding to different motivations. One such motivation, highlighted by Strauss, is the fear of persecution. Another is pedagogical: as any member of the modern academic faculty knows, not all texts (or even all arguments within some texts) are appropriate for all students or all contexts. An esoteric-minded writer may then choose to write in such a way that will transmit something to every student, while being most helpful for advanced students. Yet another motivation for esoteric writing has to do with the subject matter itself, an embryonic point in Aristotle's Nicomachean Ethics, where the Stagirite writes that each discipline requires its own methods [see Anagnostopoulos 1994, 320-362]. A difficult topic, naturally, will demand a certain kind of explanation that is not matched by the explanation of a simple concept. Some topics or questions must be approached esoterically, not necessarily because the author wishes to hide their "true" thoughtsalthough, as we have noted, that is generally true of esoteric writing-but rather because they cannot be treated in any other way. Ibn Falaquera, a 13th century Spanish Jewish thinker, offers the analogy of trying to teach a blind person about colors. Straightforward descriptions would be useless, and the discourse of the teacher would quickly fall into incoherence. The only meaningful procedure is to indicate to the student the path that the teacher took, from non-seeing to seeing and then seeing colors-and trust 
that the student has the skills to understand and apply the indications [De Souza 2018, 169-170]. This last motivation for esotericism is designated by Lemler as "essential" or "philosophical" esotericism, in which there is an "intrinsic connection between the employment of esoteric writing and the topics discussed through such writing” [12].

Lemler is interested in the approach to the creation of the world as a topic that demands esoteric writing. This is because, Lemler explains, Creation is a subject that lies at the very limits of what can be said. What is at stake is "no less than seeking to put into words something about the radical origin of everything, while language always presupposes the existence of anything of which it speaks" [14]. In support of his position, he quotes Wittgenstein's Lecture on Ethics: "the right expression in language for the miracle of the existence of the world, though it is not any proposition in language, is the existence of language itself" [Zamuner, Di Lascio, and Levy 2014, 50]. Lemler concludes that Creation is a question that we cannot avoid, and yet "every attempt to answer it necessarily leads to inextricable problems regarding the correct way to speak of it" [14].

A central problem with esoteric writing is that readers can never be sure that they have grasped the author's "true" views. It is very easy to be distracted by an insignificant remark placed in the text precisely to throw the reader off. Even competent readers who may understand most of the author's allusions will still have to make critical hermeneutical decisions. This is the case, as Lemler shows, for readers of Maimonides' Guide of the Perplexed, a locus classicus in medieval Jewish philosophy on the problem of Creation. Maimonides presents no fewer than three theories of Creation without clearly and unambiguously taking any sides. It is up to the reader to figure out what is Maimonides' “real” position. As early as Maimonides' medieval readers, and continuing through modern academia, different scholars have attributed to Maimonides each of the three theories. The dispute continues, with strong arguments on all sides, and no one can truly say what Maimonides personally "really" thought about Creation (on which more below).

With this idea in mind, Lemler is to be applauded for the very sensible choice of bypassing any search for the author's "true" intention in the texts that he studies. What matters is the text, the questions raised therein. The esoteric text is language without author [20, citing Barthes 1977]. The challenge for readers of an esoteric text is not (or should not be) to understand what some author meant to say regarding Creation; rather, it is to seize on what the text has to say on the subject. Hence, Lemler's broad project in this book is to analyze esoteric strategies of writing not as devices that hide an 
author's true views, but as attempts to expose the limits of language "within and through language". Such strategies of writing are a means to "know, as much as possible, something that is inherently outside the field of human knowledge" [21].

Lemler's project, then, is one where the philosophy of language crosses over into epistemology and vice-versa. Esoteric writing, in Lemler's formulation, manifests not merely as a method of writing, but as a means for knowing about the world, and here-crucially for Creation-as a means for articulating, however tentatively, the limits of the world and of language.

Lemler follows this thought-provoking theoretical scaffolding with individual chapters dedicated to six medieval Jewish philosophers: Saadia Gaon, Abraham ibn Ezra, Maimonides (two chapters), Gersonides, and Isaac Albalag/Hasdai Crescas (together in one chapter). He closes with a brief conclusion. Lemler chooses these thinkers because, in his description, they each espouse a distinct view of the origin of the world.

While the choice of Abraham ibn Ezra and Maimonides is clear-these authors have long been read esoterically, and they employ clear esoteric rhetorical markers - the choice of the other thinkers for a work on esoteric language is something of a question mark. Saadia is not known as an esoteric writer, and Gersonides is most certainly not an esotericist-he writes vigorously against the practice in the introduction to his Wars of the Lord [Feldman 1984, 100-101]. Crescas has likewise not been known as an esotericist, but Lemler makes a persuasive case for esotericism in chapter 6 by investigating an explicit contradiction in Crescas' treatise, Light of the Lord. Many other authors could have been included, including openly esoteric authors such as Joseph ibn Kaspi [Sackson 2017] or Levi ben Abraham ben Hayim, the persecuted author of an allegorical treatise on Creation [cf. Halkin 1966, Kreisel 2004], as well as authors who adopt esotericism to some extent, such as Ibn Falaquera [De Souza 2018, 44] and the onetime student of Crescas, Joseph Albo [Ehrlich 2009].

To summarize each chapter briefly: chapter 1, on Saadia, studies the different treatments of Creation in the Book of Beliefs and Opinions and the commentary on the Sefer Yezirah (Book of Creation). According to Lemler's reading of these texts, in the Book of Beliefs and Opinions, we have an argument that Creation has taken place, although humans are not able to represent what it was: it cannot be known in itself; we can only know that it has occurred. The commentary on Sefer Yezirah, however, insists on the will to know: it explains the how of Creation, its principle and order, as if it were an 
ordinary object of knowledge that can be known. (Hence, Lemler compares the commentary on Sefer Yezirah to Kant's vice of Schwärmerei, enthusiasm that blunts the self-critique of reason). While the chapter does contain some interesting material about language, it is primarily epistemological in approach.

Chapter 2, on Abraham ibn Ezra, takes up his well-known contention that "the Torah speaks in the language of humans", which in Lemler's reading means that the language of the Bible represents "natural" language (i.e., everyday language) rather than scientific discourse. The biblical narrative of Creation is an attempt to describe in terms accessible to all and any an experience that is by definition impossible to know. There is no term in natural language that can be used to designate the creation of the world, and Creation can only be understood, therefore, in terms of analogy with what has been created in the world [45].

Chapters 3 and 4 focus on Maimonides and the Guide of the Perplexed. Lemler was wise to write two separate chapters on Maimonides because Maimonides is not only a central figure of medieval Jewish philosophy, he also theorized esoteric writing to a greater extent than any of the other philosophers in Lemler's book. Due to the influence of Maimonides, esotericism became a more central concern in post-Maimonidean Jewish philosophy. In the paragraphs to follow, then, I will reconstruct the arguments in the remaining chapters in greater detail.

Chapter 3 introduces the basic problems of Maimonidean esotericism, primarily with attention to indications contained in the introduction to the Guide. As I have argued elsewhere, the introduction to the Guide is a selfcontained work that stands on its own as a theoretical expression of the Maimonidean project. It is a statement of Maimonides' method and anxieties concerning the use of esoteric writing. Much of Jewish philosophy between Maimonides and Spinoza builds upon concepts brought forward in this introduction [De Souza 2018,4-5]. Lemler shows that in the interpretive tradition of the Guide two groups of readers have emerged: esotericists and exotericists. Esotericists, à la Strauss, are attentive to potentially underlying meanings in the text. For esotericists, Maimonides' strong or numerous arguments in favor of any one position in the Guide are a priori suspect, a stratagem to throw off casual readers. Exotericists, on the other hand, tend to focus on the arguments of the Guide rather than on its avowedly esoteric method. The two camps come away from the Guide with contradictory, mutually exclusive ideas about Maimonides' “true” opinions. 
Lemler's intervention consists of dispensing with any search for what Maimonides "really" meant to say. He contends that Maimonides' intention is precisely to place the reader in such a quandary:

Maimonides himself, through his introductory remarks, has placed the reader faced with the text of the Guide within an epistemological situation where it is impossible for the reader to have access to the position of the author. [75]

Chapter 4, therefore, focuses on the text rather than on the author. In his approach to the Maimonidean issue of Creation-a subject on which much ink has been spilled ${ }^{2}$ - Lemler centers his analysis on what he calls the "Maimonidean Principle":

No inference can be drawn in any respect from the nature of a thing after it has been generated, has attained its final state, and has achieved stability in its most perfect state, to the state of that thing while it moved toward being generated. [Guide 2:17: Pines 1963, 295].

Lemler deploys this passage to argue that the ambiguity of the Guide on Creation might be better explained by the difficulty of speaking of the subject rather than an authorial desire to dissimulate his own opinion. In his reading of this Maimonidean Principle, Lemler argues that the text advocates both the religious and the Aristotelian views of Creation as valid. The Principle, according to Lemler, leaves open the possibility of Creation de novo and ex nihilo, preserving the sense of the world as a miracle, an irruption of the divine will into the laws of nature. "To decide that the world is created means to decide to consider its existence as having meaning" [107]. Concurrently, the Principle allows for the possibility of the world as an Aristotelian, uncreated brute fact, an object strictly ruled by laws of nature, hence, something that can be known and described. This intellectual practice of observing and knowing the world, in Lemler's reading of Maimonides, is the highest ideal for human life according to Judaism [107]. In this manner, both the religious and the Aristotelian readings of Creation are valid even though they may seem mutually exclusive. Lemler concludes that this apparent contradiction should be read as producing an original theory of Creation: the religious, created world appears to us as if it is objective and uncreated. The position of the Guide on Creation, then, is to project subjective conditions of knowledge onto an objective world [108].

2 Readers have identified Maimonides as a Platonist, an Aristotelian, a religious Jew, or a sceptic on the matter of Creation. See Lemler 68 n6. On Maimonides and scepticism, see Stern 2013, 132-249. For Maimonides as holding the traditional religious view, see Seeskin 2005. 
Chapter 5, on Gersonides, illustrates the ideological diversity of medieval Jewish philosophical writing. Alongside those who employ esoteric writing to a greater or lesser extent, there are thinkers like Levi ben Gershom (widely known as Ralbag or Gersonides) who purposefully dispense with the esoteric program. Arguing directly against Maimonides, Gersonides conducts a radical critique of esotericism; and as a correlate, he insists that Creation is a concept that is fully within the sphere of human knowledge and which can be conclusively demonstrated. As Lemler points out, Gersonides rejects the notion of essential esotericism (according to which certain subjects require an esoteric presentation), as well as the notion of political-religious esotericism (according to which esotericism is required because of the potential danger of persecution for the philosopher). Unlike Maimonides, Gersonides

does not recoil from a clear and univocal account of heterodox doctrines, while acknowledging that such an account should be preceded by a prior preparation that will render them acceptable. [120]

While the account of Creation in the Hebrew Bible is not itself a demonstration, for Gersonides it constitutes a haysharah, that is, guidance or an indication. Such haysharah is meant to convey only that Creation is a subject that should be analyzed and demonstrated by science, but without prior assumptions or conclusions. I employ the term "science" deliberately, as Lemler outlines how Gersonides-atypically for his time-attributed singular importance to empirical observation in the construction of scientific hypotheses [126-127]. That is not to say that the biblical text has no significance; rather, it means that Gersonides is located within a "hermeneutical circle" [128]. Understood as haysharah, the biblical account is true and does not contradict reason, which should be developed freely and independently; but the rational project has no meaning unless the biblical account is possible.

Last, Lemler turns his attention to Gersonides' critique of the Maimonidean Principle (enunciated earlier). While Maimonides employs the principle to insist on a radical break between the before and after of Creation-thus opening the possibility for Creation ex nihilo-Gersonides finds Creation ex nihilo to be a logical impossibility equivalent to the simultaneous existence of two contraries, or the idea of God creating another God [130-131]. The Maimonidean Principle, Gersonides argues, makes it impossible for the world as it is to be an object of knowledge because the nature of its cause cannot be known. Instead, Gersonides develops his theory of Creation along the lines of the Platonic pattern (Creation de novo but "from something", ex aliquo). For Gersonides, only the hypothesis of a primordial preexistent body 
(in the minimal sense, without form or nature, fluid or ungraspable), which cannot be known directly but can be known logically, is the only theory that can make sense of the universe as it is. Such a hypothesis "makes it possible for reason to grasp or to describe its own origin" [136].

Chapter 6 is on Isaac Albalag and Hasdai Crescas, philosophers who have been characterized as extremely divergent from one another. Albalag has become known as a partisan of the theory of "double truth" and a strict Aristotelian [Touati 1962]; Crescas has come down to us as a conservative religious thinker [Davidson 1983]. In this chapter, Lemler intends to dispel both of these stereotypes. He argues that both thinkers agree that a continuously created world is more appropriately attributable to God than a world created de novo [139]. Once again, Lemler interprets the use of esoteric language not as an attempt to hide some opinion but as a philosophical practice that implies something about the nature of the subject [140].

On Albalag, Lemler shows that the notion of a "double truth" (which maintains the simultaneous validity of religious and scientific accounts, even if they are contradictory and mutually exclusive) was never seriously held by any Latin philosophers. Some scholars of Albalag have interpreted his allegiance to the idea of "double truth" as a case of strategic and insincere dissimulation along the lines of the religious-philosophical esoteric paradigm (fear of persecution) [144n3]. Lemler focuses on the meaning of this doctrine as proposed by Albalag rather than on his sincerity. In his view, the doctrine of a "double truth" is the theoretical foundation for a specific Jewish philosophical practice in that it gives the Jewish philosopher complete freedom of inquiry, on the one hand, while guaranteeing the autonomy of the biblical text, on the other. Rational inquiry and text come together in exegesis, which brings that philosopher into rapport with a given truth. The philosophical exegesis of the biblical text becomes a "spiritual exercise", in the sense given to this term by Hadot and Foucault [149]. Lemler emphasizes that the dispute is not between two sources of knowledge, but rather between truth and its representation: the philosopher knows, scientifically, that the First Cause creates the world continuously, but believes that Creation takes place within a temporal framework, as it is represented in the biblical text. There is a back-and-forth between the concept and its "inseparable but inadequate" representation [152]. The philosopher's allegiance to the biblical text implies that the philosopher, like simple religious believers, has a faculty of imagination, while the

allegorization of the temporal account of Genesis is the perennially renewed effort to rediscover the concept through the imagination. [152] 
Albalag's solution, then, is an epistemological solution for the problem of the Creation of the universe.

Lemler then goes on to discuss Crescas. He focuses on the fact that in Crescas' treatment of Creation, Crescas offers several arguments against Creation de novo, before hastily concluding that Creation de novo, which he has just refuted, is the "absolute truth" [Weiss 2018, 276]. Such a procedure, consisting of an explicit contradiction, is a hallmark of philosophical esoteric writing, as it leads the reader to question just what is Crescas' real opinion. Eschewing again any attempt to learn what Crescas "really" thought, Lemler moves on to focus on Crescas' arguments. As he notes, Crescas maintains that the biblical text imposes a notion of Creation de novo which maintains God's voluntariness in the process of creating world(s) ontologically dependent on God, but which also raises questions concerning the extent of divine power. ${ }^{3}$ Crescas argues that the true condition of possibility for the Torah to exist, however, is not Creation de novo but Creation tout court.

Why, then, does the biblical text maintain that Creation is specifically de novo? As Lemler puts it, the problem is to learn why an all-powerful God would wish to be represented as less powerful since stating that God merely creates de novo implies a less powerful God than depicting one who creates continuously. Lemler resolves the conundrum by arguing that Crescas relies on a principle of divine wisdom (which Lemler also identifies in Saadia Gaon), according to which "infinite divine power can only manifest in the human realm by paradoxically limiting itself, by inscribing Creation within the length of a narrative" [168]. The appeal to an unknowable divine wisdom is meant to resolve a difficulty that is both conceptual and epistemological. The biblical belief, contrary to reason, becomes a paradoxical means to imprint a certain representation onto the idea of Creation [169]. Lemler concludes that, for Crescas, we might have to believe in the newness of the world in order to learn (connaitre) its Creation [169].

It is this paradox, which Lemler reads in both Albalag and Crescas, that allows us to get beyond esoteric agendas and double-truth theories. If these contradictions are something beyond a political strategy, they suggest that the concept of Creation is a paradoxical structure, a logical consequence

3 Crescas maintains that continuous Creation implies the formation and destruction of an infinite number of worlds, which raises the question of why God would not simply create the best of all possible worlds. See Weiss 2018, 276-277. 
of the idea of God and God's relation to what is other than God, a structure that cannot be apprehended unless it can represent itself as limited in scope [171].

In his conclusion, Lemler insists that our strategies of reading medieval Jewish sources on Creation cannot end where esotericism begins. Instead, he argues that the treatment of Creation implies a new practice of philosophizing, and indeed a modification of what philosophy is. While esotericists have emphasized the modifications that philosophical inquiry operated on religious beliefs and texts, such as rationalization and demythologization, Lemler points to the idea that the tension between religion and philosophy brings dramatic changes to the notion of philosophy and its practitioners, raising the status of a philosophical demonstration, in their eyes, to that of religious revelation [181].

Lemler's study significantly advances the debate on the interpretation of medieval Jewish texts. It offers a path beyond the esoteric-exoteric paradigm, opening a new vista where esoteric techniques are read not as a desire to conceal. Rather, esoteric writing on Creation embodies a fundamental epistemological quandary about what can be known of the origins of the world, and, hence, of language and knowledge. Through this process, religion and philosophy both emerge autonomous, but scathed and transformed. Above all, it is the subjects - the readers - who are transformed by the investigation into Creation, and who become aware of their own epistemological limits.

\section{BIBLIOGRAPHY}

Anagnostopoulos, G. 1994. Aristotle on the Goals and Exactness of Ethics. Berkeley.

Barthes, R. 1977. “The Death of the Author”. Pp. 142-148 in Image, Music, Text. London, UK.

Boas, G. 1953. “Ancient Testimony to Secret Doctrines”. The Philosophical Review 62: 79-92.

Davidson, H. 1983. "Medieval Jewish Philosophy in the Sixteenth Century". Pp. 106-145 in B. D. Cooperman ed. Jewish Thought in the Sixteenth Century. Cambridge, MA.

De Souza, I. H. 2018. Rewriting Maimonides: Early Commentaries on the “Guide of the Perplexed". Berlin. 
Ehrlich, D. 2009. The Thought of R. Joseph Albo: Esoteric Writing in the Late Middle Ages. Ramat-Gan. [Hebrew]

Feldman, S. 1984. trans. Levi ben Gershom (Gersonides): Wars of the Lord. vol. 1. Philadelphia.

Halbertal, M. 2007. Concealment and Revelation: Esotericism in Jewish Thought and Its Philosophical Implications. Princeton, NJ.

Halkin, A. S. 1966. "Why Was Levi Ben Hayyim Hounded?” Proceedings of the American Academy for Jewish Research 34: 65-76.

Kreisel, H. 2004. ed. The Livyat Hen of R. Levi ben Abraham: The Work of Creation. Jerusalem.

Melzer, A. 2014. Philosophy between the Lines: The Lost History of Esoteric Writing. Chicago.

Pines, S. 1963. trans. Moses Maimonides: The Guide of the Perplexed. Chicago.

Sackson, A. 2017. Joseph Ibn Kaspi: Portrait of a Hebrew Philosopher in Medieval Provence. Boston.

Schwartz, D. 2005. Central Problems of Medieval Jewish Philosophy. Boston.

Seeskin, K. 2005. Maimonides on the Origin of the World. Cambridge, UK.

Stern, J. 2013. The Matter and Form of Maimonides' Guide. Boston.

Strauss, L. 1952. Persecution and the Art of Writing. Chicago. Repr. 1988.

Talmage, F. 1999. “Apples of Gold in Settings of Silver”. Pp. 108-150 in B. D. Walfish ed. Apples of Gold in Settings of Silver: Studies in Medieval Jewish Exegesis. Toronto.

Touati, C. 1962. "Vérité philosophique et vérité prophétique chez Isaac Albalag”. Révue des Études Juives 121: 35-47.

Weiss, R. 2018. trans. Hasdai Crescas: Light of the Lord (Or Hashem). Oxford.

Zamuner, E.; V. Di Lascio; and D. K. Levy. 2014. edd. Ludwig Wittgenstein: Lecture on Ethics. Malden, MA. 